\title{
IMPLEMENTATION OF EDPUZZLE TO IMPROVE STUDENTS' ANALYTICAL THINKING SKILL IN NARRATIVE TEXT
}

\author{
Amaliah \\ SMPN 2 Sidoarjo, Jalan Raya Ponti Sidoarjo - Jawa Timur \\ e-mail: amaliahsda@gmail.com
}

\begin{abstract}
Digital learning has become one of the demands of life to prepare students to become part of global society 5.0. as cultured human being. For this reason, it is very important that students learn to be creative, collaborative, communicative, and able to think critically. However, to achieve those all, the teacher really has to work hard in designing $4 \mathrm{C}$ learning. The purpose of this research is to describe the implementation of Edpuzzle to improve the students'analytical thinking skill in Narrative text at SMPN 2 Sidoarjo in the academic year 2018/2019 by using Edpuzzle in the even semester. The method used in this research is case study. It develops a detail background, case, investigation to solve a problem. The results obtained are: (1) The use of Edpuzzle can improve students' analytical thinking skill, especially in Narrative text at SMPN 2 Sidoarjo (2) The use of Edpuzzle in the classroom is conducted and implemented with PISA method (Preliminarily, Intensive learning, Self-study and Assessment). This application is specifically used to overcome students' understanding and analytical thinking skills at a higher level. Students also increase their creativity in creating writing content that educates and promotes the Indonesian stories to the international languages.
\end{abstract}

Keywords: edpuzzle, analytical thinking skill, narrative text. 


\section{BACKGROUND}

In this era of global society 5.0, teachers should make new possibilities, new breakthroughs to prepare a golden generation of Indonesia who are advanced, creative, and still refined. This new breakthrough is expected to continue to grow also in the souls of the current generation. For this reason, there is a need for $4 \mathrm{C}$ learning that includes creativity, collaboration, communication and critical thinking. Mc Grane in Putra (2012: 35 ) states that the ability of $4 \mathrm{C}$ is a compulsory ability in the 21 st century, because it is necessary for innovation by utilizing digital technology as an integrated part of the learning process. Technology-based learning is now increasingly rapid in line with the digital revolution. Learning narrative text becomes very important material in English language lessons. The ability to think analytically has become a necessity for students to live in society, so that they are able to solve the problems.

Designing activities and think how students learn well and can be involved in HOTS learning is often a challenge. Two main obstacles that the teacher had to solve are: (1) learning process tends to take a long time. In the process of analysing narrative text, students should be more creative in thinking independently. (2) Students need to be guided in making, building their own thinking creativity. In this case an app is needed. Teacher can make use of online media by creating learning content at www.Edpuzzle.com. Then after creating the online class there and serve a media of learning content, teacher shares the link of digital class to students via whatasapp group. The students click it, then open the android application version, called as Edpuzzle, downloaded from playstore. As explained by Walker (2017: 128) a Finnish teacher, that in order to develop mastery, teachers should teach the fundamentals, use technology, guide, look for evidence, and agree on values with students. By using technology, the teacher guides students in analyzing, looking for evidence and agrees on the assessment for mastery development, while to increase student analytical thinking skill, it also needs the touch of the teachers' creative hands.

Media is a messenger. Media is a medium to simplify the process of students getting meanings. This process will explain how students are able to grasp meaning, analyze, compare, texts well in learning English. The function of the media in general according to Susilana and Riyana (2007: 9-10) is a means of assistance, interconnected with each other, relevant to competence, accelerating the learning process, improving quality, and laying a real basis for thinking reducing verbalism. It drives the writer to create a learning process which make use a tool which can easily be used, both by teachers and students.

Teachers can develop their questions, especially the analytical questions to get high order thinking problems, since narrative always involves a process of conflict, complication, problems to be solved. It will make the students get moral lesson from each story they learn. Darma (2005: 133) mentions observations that demand a depth that most people do not have in the delivery of morals or message, the development of paths that bring renewal. The presence of an android or smartphone according to Wahyudin (2018: 33) can facilitate the learning process, because it can be a reliable, easy, fast learning source because of its ability to transfer knowledge in the involvement of many senses, multimedia. Applications on Android are used to access learning material, work on quizzes, discuss.

Measurement of learning outcomes is the goal of the assessment of results (Susanto, 2015: 89). The results assessment according to Susanto (2015: 68) was given in the form of a test, which could be a written test or an oral test. Written tests to measure knowledge and understanding can be short answer tests in five different 
formats: (1) unstructured, (2) complete, (3) right and wrong, (4) match, (5) multiple choice. Assessment is the process of gathering information about two things, namely regarding the development of learning and learning success. From various kinds of tests, the authors determine to use number 2 and 5, multiple choice and complete. Which can easily measure the analytical thinking skill outcome data and complete the story map to measure

Analyticall thinking skills in Wikipedia are the skills to do or performing analysis. These skills include the ability to apply logical thinking to break down complex problems into its component parts. Richard J. Heuer Jr. in Wikipedia explains that analytical thinking is a skill such as driving, carpentry that can be taught, learned, and improved through practice. (https://en.wikipedia.org/wiki/Analytical_skill)

One of the most important intelligences for generating creativity is analytical thinking skills. Analytical thinking skills according to Sani is the ability to judge a person's ideas, see the strengths (strengths) and weaknesses (weaknesses), and provide suggestions for improvement (improvement) (2019: 100). Analytical strategy is a stepby-step process according to logic, students can skillfully think analytically using the skill demonstration method, simplifying the problem (2019: 92).

With this analytical skill, someone becomes an expert in making decisions. According to Sani based on the consensus of experts, the skill to analyze is to examine the intended inferential relationship and the actual relationship of several statements, questions, concepts, descriptions, or other forms of representation to express beliefs, conclusions, experiences, reasons, information, or choices. The sub-skills are examining ideas, identifying arguments, identifying reasons and claims. (2019: 23)

Analytical thinking skills are a requirement for higher order thinking. Bloom in Kiong et al (2010) states thinking cognitive analysis is asking information, differentiating, organizing, adding answers with existing knowledge or understanding. Whereas metacognitive differentiating, organizing, attributing (connecting). To improve students' thinking skills, teachers develop learning activities using the android application and also form assessments using analytical thinking skills theory. When learning the teacher also provides Story maps for student worksheets to analyze narrative stories. The writer designs a learning process which make use the tool Edpuzzle. This learning process is called as PISA (Preliminary, Intensive Learning, Self-study, Assessment). PISA which is usually a series of international tests to measure students' critical thinking skills (Program of International Study Assessment) in this case study is adapted into a systematic learning sequence in order to improve analytical thinking skill. As Sivakumar argues that can be done anywhere, anytime, motivating learning experiences that are relevant to the location and context (2015: 216).

Edpuzzle is a tool or a media which can be used by all the teachers to make interesting and interactive video lessons and materials from any sources of learning video such as YouTube, Khan Academy, Crash Course. Using Edpuzzle, teachers easily create interactive video lessons for students. Teachers can track students' progress with hassle-free analyticals as the teacher's design. Any videos can be made as lesson by choosing a video, giving it certain analytical questions, and track students' completeness ans accountability. Teachers can check if their students are watching the video that the teacher designs previously, how many times they're watching each section, and if they're understanding the content. It is compatible for students to access using their own android, even the teacher has to design it previously using laptop and share the link to whatsapp group. 


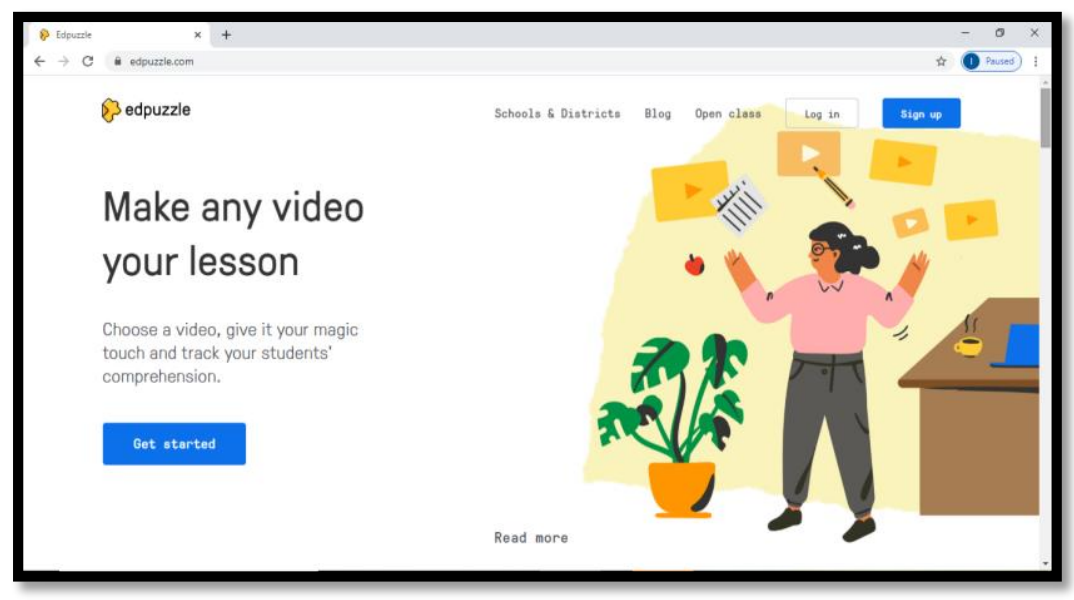

Richard and Rodgers, two renowned language education experts on Content Based Instruction, state that teachers are able to match students' interests and needs with interesting and meaningful content. CBI provides many practical advantages because the activities of language classes are so specific, make students think and learn through language. Richard and Rodgers (2002: 220). In addition, content based instruction makes students have a variety of skills and learning skills (Richard and Rodgers, 2002: 220). Thus, in reading English text material, students are able to analyze narrative stories. The idea of using this Edpuzzle is from the phenomenon of the presence of a booming android, whether they are old or young, or they are teachers or students, android is always taking part in life.

The teacher designs a learning process according to HOTS (higher order thinking skill) so that students are able to think analytically. Based on the description, the problem can be formulated, namely: (1) Can Edpuzzle improve the students'analytical thinking skill in learning narrative text at SMPN 2 Sidoarjo? (2) How to increase the students'analytical thinking skill in learning narrative text at SMPN 2 Sidoarjo using Edpuzzle?

\section{RESEARCH METHOD}

The research method which is used here is case study. Baxter \& Jack (2008) state that a case study is a contextual investigation of a phenomenon. From the statement, it can be seen that it is a study which investigate a phenomenon in a certain context. It is suitable with what the writer as a teacher did. A case study is a research with a detail background or a subject or an event, or a document. This reseach was conducted at SMPN 2 Sidoarjo, Jl Raya Ponti Sidoarjo in the academic year 2019/2020, especially to the students of ninth grade in the even semester.

Yin in Karlsson (2016) mentions the three kinds of case studies. They are explotary, descriptive, and explanatory. Exploratory case study is a study to understand how a thing takes place. Descriptive case study is a study to illustrate and describe a thing in the context in which it occurred. Explanatory case study is a study to explain causal links between the case and its context in a real-life situation. From the tree subdivision of case study, the writer chose the descriptive one to describe a thing, a media which used here in a certain context. The context was implementation of Edpuzzle, it occured to junior high school students, especially at the ninth grade of SMPN 2 Sidoarjo. The analysis carried out is developed by using documents, such as 
the analytical questions, process of learning documents observed by another teacher, observation sheet.

The flowchart of implementation from input, process, outcome and impact can be seen as follows:

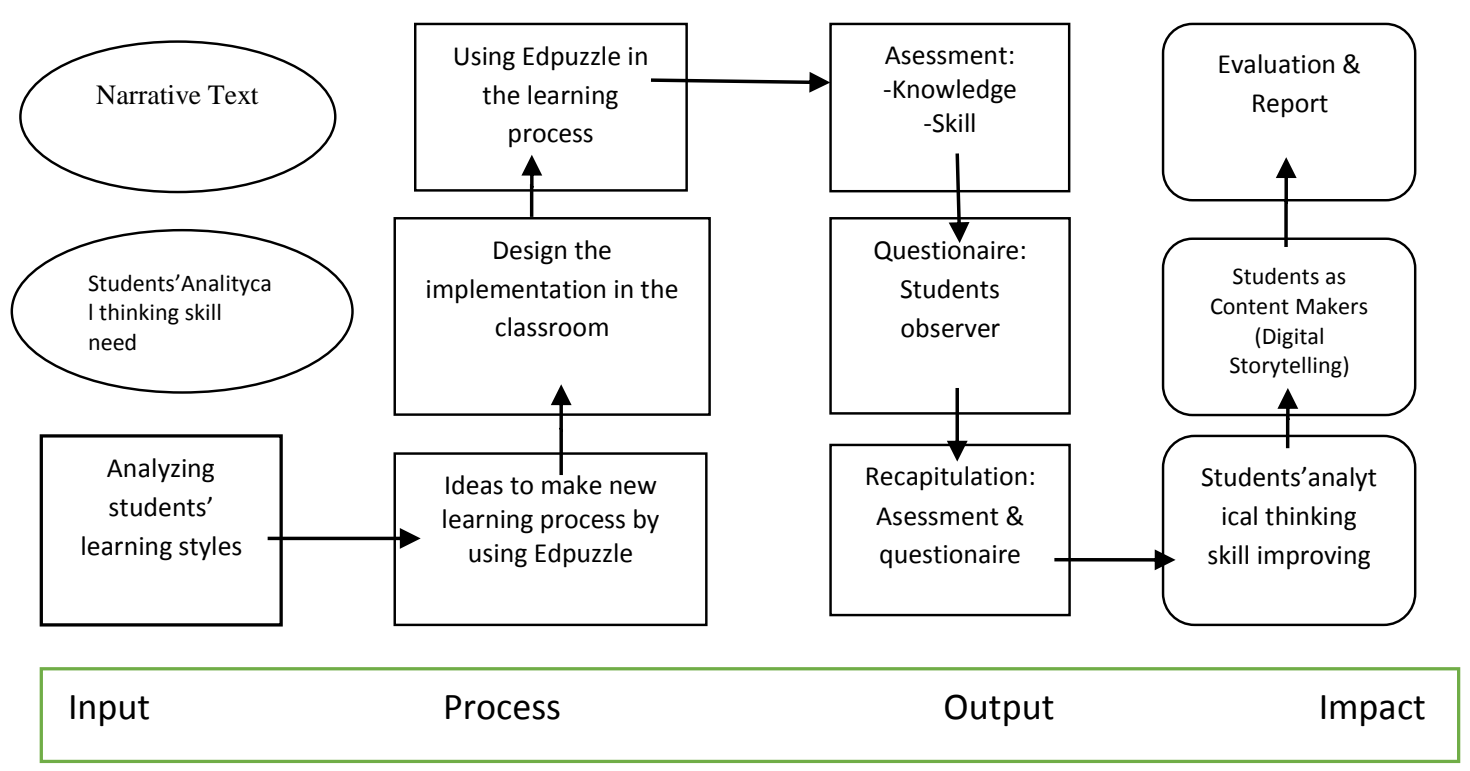

The method of implementation of this learning process uses the appropriate IDEAL stages which is developed by Bransford and Stein in Sani (2019: 29). In the first step, Identify the problem, the writer formulates the problem, reviews of literature, then defines it by formulating the hypothesis, operational definition and research variable. Next, exploring possible strategies by finding ideas, designing research questionnaire, other instruments, choosing and modifying the methods, media. While in look back step, there is assessment of process and assessment of result. Finally, the researcher writes the report.

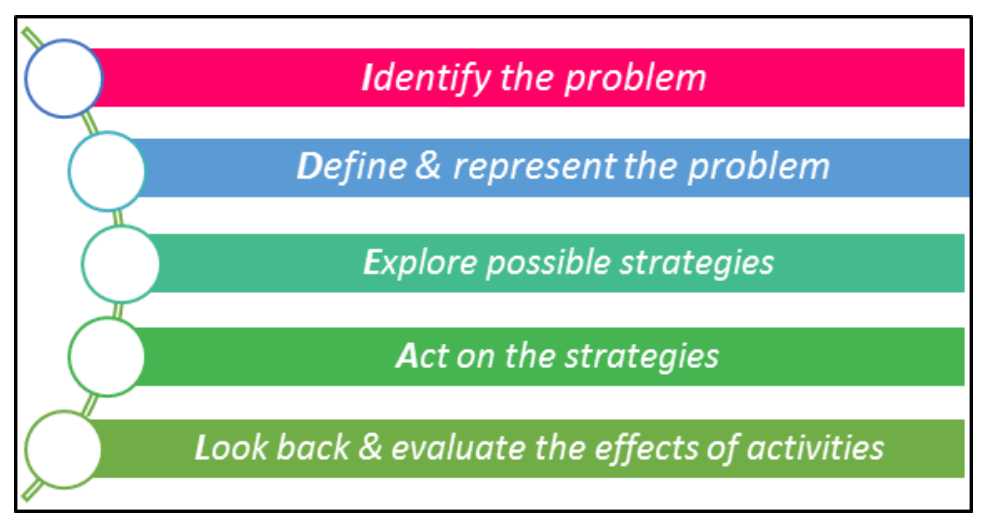

The media used in this learning process is Edpuzzle. the steps are: choosing the material in the video, we can find the options inside it such as YouTube, Khan Academy, Crash Course. Then, edit it to make it more efficient to be learned and add questions. The questions can be set in certain point of the learninig video. The amount of the questions depends on the teacher. For the analytics questions given to the students are based on higher order thining skills. 


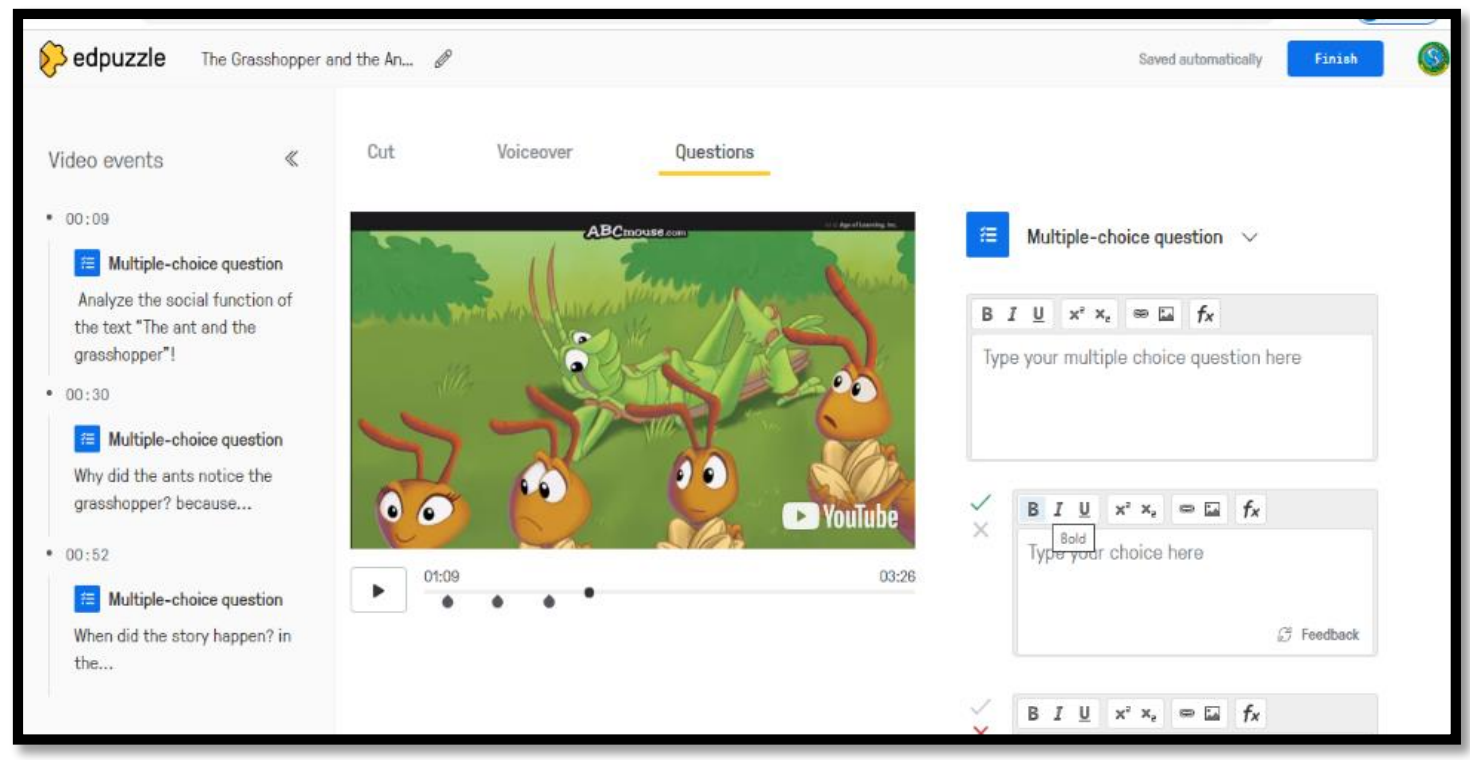

There are two kinds of data collected, they are data of process and data of result. In the data of process, teacher together with the observer observe the analytical thinking process of the students' activities such as asking information, differentiating, organizing, adding answers with existing knowledge or understanding. Whereas in metacognitive analytic, there must be activities of differentiating, organizing, attributing (connecting) undergone. To take data of result, the teacher provides students with analytical thinking skill questions given online.

\section{DISCUSSION}

\section{A. Implementation of Learning Process}

In the Action step, there must be implementation of learning process. Implementation of Edpuzzle in learning process is divided into four stages, they are:

1) Preliminary $(\mathrm{P})$

The teacher as a facilitator provides direction on the learning scenario on that day, motivating the importance of learning about English narrative texts as an inculcation of moral values. Students have previously received the link address to download the Edpuzzle application given to the whatsapp group. In the preliminary, there is an observation stage. Students concentrate on observing the videoshow by pressing the video "The Ants and the Grasshopper" available there. Then the students listen and the task is to look for verbs or the activities of the characters in the video. Students record the words or activities they hear in the story of the show, then try to understand the story through observation videos.

2) Intensive Learning Activities (I)

After observing the video animation, students learn intensively then explore information, analyze the story given. The students comparing two characters, grasshopper with ants. Students look for similarities and differences. The results of the analysis are discussed. Then look for the first conflict, the second and also the first resolution, the second problem in the narrative story in the form of the fable. The teacher provides them a story map to analyze it. 
3) Self-study Activities (S)

After observing, exploring and analyzing, students study independently in groups (self study), discuss the material and questions in the application. On the Edpuzzle, there are some exercises that students must do in the form of questions to train high-level thinking skill especially in analytical thinking skill. The result will be graded automatically to the teacher's account.

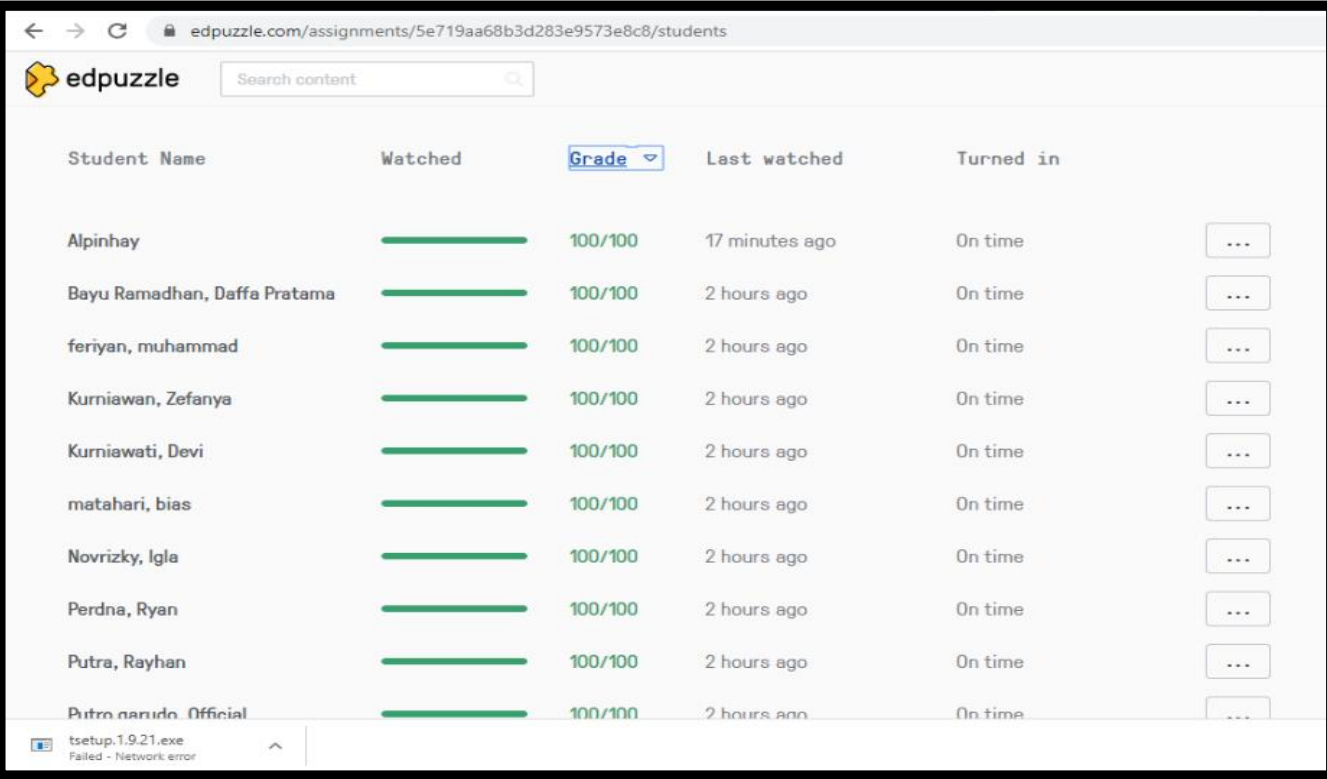

4) Assessment Activity (A)

The assessment is carried out both during the process, also after learning. The assessment process is carried out by the teacher by going around looking at students 'thought processes, students' performance. Meanwhile students' analytical thinking skill is measured by high order thinking skills questions. While the results assessment is done by giving daily tests. At the end of the lesson, students are guided by the teacher to make conclusions together about the fable and moral values. Students learn and get the moral values of hard work and never underestimate the future challenges they will face. Reflection on how the students 'ability to deliver the results of the discussion, whether students' difficulties they face, find solutions to things that are considered difficult together. They also get group assignment to make digital storytelling using android app they have such as kinmaster, videomaker and etc. This story was discussed by each group and made a digital storytelling design in their own version using applications both on mobile phones and on computers. The teacher gives advice when students have difficulties to create it using such as video maker with their android. As Dave Meier mentioned in his accelerated learning, that the teacher is the context maker, while the students are the content makers (2000: 15). So the context given by the teacher is the making of a narrative story video.

\section{B. Results and Discussion}

During the learning process, the observer observes and records all activities that occur. Observation and assessment of student activities is conducted to determine students' analytic skills in English texts, both before and after the use of Edpuzzle 
media. After completing the whole series of learning, students have to answer questions in the form of analytical skills assessment in the narrative text. The use of Edpuzzle can be in blended learning, such as in the classroom, in groups or in collaboration, communicate talking about stories, think critically about the problems in it and create videos outside the classroom. This is flexible, and it depends on the creativity of teachers to teach students. To learn, watch, listen, answer or practice quizzes in the application of Edpyzzle. The teacher can easily evaluate the extent to which students understand various narrative texts and higher order thinking / HOTS (higher order thinking skills). The data result shows that the student learning outcomes was $88.88 \%$ complete and $11.1 \%$ have not been completed.

Students'Analytical Skill Score Result
\begin{tabular}{|l|c|c|c|c|c|c|c|c|c|c|c|r|}
\hline $\begin{array}{l}\text { Problem } \\
\text { Number }\end{array}$ & 1 & 2 & 3 & 4 & 5 & 6 & 7 & 8 & 9 & 10 & TOTAL & AVERAGE \\
\hline Before & 3,61 & 3,5 & 3,61 & 3,72 & 3,42 & 3,58 & 3,56 & 3,75 & 3,83 & 3,72 & 36,327 & 3,63 \\
\hline After & 4,28 & 4,389 & 4,19 & 4,36 & 4,22 & 4,39 & 4,25 & 4,139 & 4,25 & 4,5 & 42,972 & 4,29 \\
\hline
\end{tabular}

From the table above it can be seen that there are significant differences in the process data, especially student analytic skills, so that it has a direct impact on student learning outcomes that increase creativity. Students' analytic skills that were originally from the poor category became very good, as well as excellent student completeness, from $88.88 \%$ of students who completed their studies, or 32 students from a total of 36 students, that obtained from their tests.

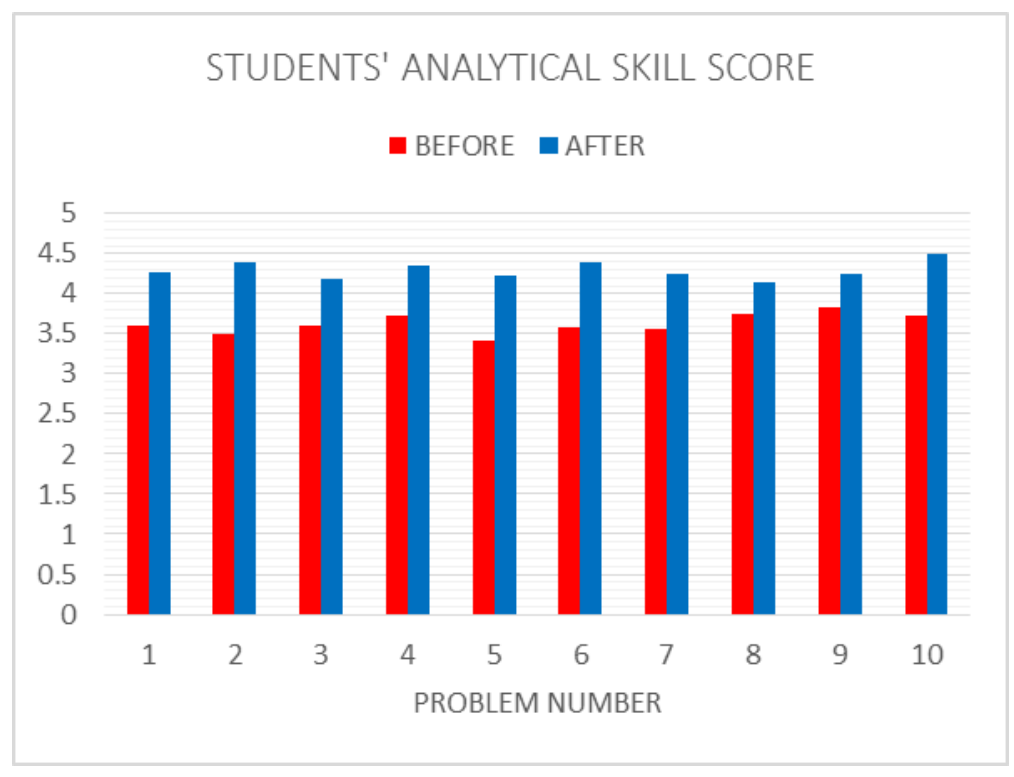

Students are able to examine ideas, identify arguments, identify reasons and claims examine ideas, identify arguments, identify reasons and claims as proposed by Sani (2019: 23). Then the teacher provides activities such as skills demonstration methods, simplifying problems. The teacher also formulates an assessment that triggers students' analytical power such as asking information, differentiating, organizing, differentiating, as well as connecting, concluding, giving reasons, choosing, expressing experiences. 

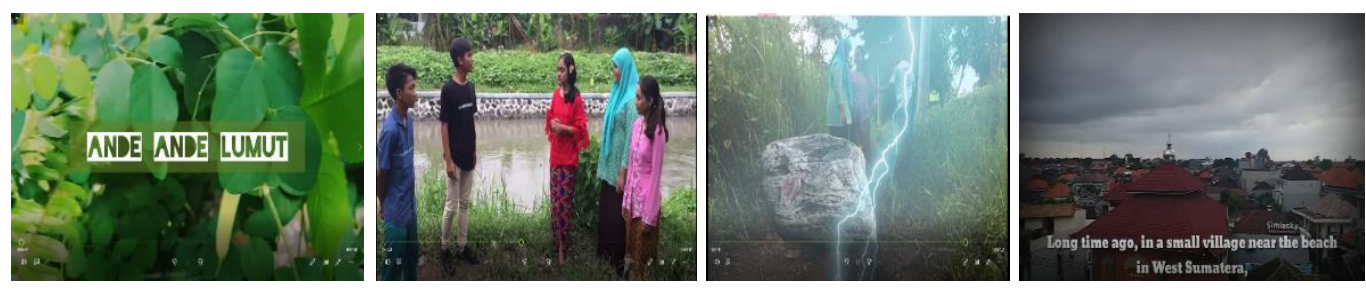

The Edpuzzle learning media that used here highly meets the media requirements proposed by Suyatno (2009), including meaningful and purposeful, safe, full of messages and information, making learning easier, practical and easy to use, according to psychiatric and development interesting and challenging child. So that after the students apply their analytical thinking skills increase.

\section{CONCLUSION}

The use of Edpuzzle in the ninth grade of SMPN 2 Sidoarjo can improve students' analytic thinking skills, it is very useful because developes the context and content in accordance with the times in the industrial revolution era 4.0 which is a challenge for future teachers now to make students a literate and creative generation;

The use of the Edpuzzle application in the ninth grade of SMPN 2 Sidoarjo can improve students' analytic thinking skills through systematic learning methods, from initial introduction (Prelimary), intensive learning (Intensive learning) guided by the teacher, independent learning (self-study), to Assessment. The teacher as a facilitator needs to provide activities that trigger students' analytical skill such as examining ideas, identifying arguments, identifying reasons and claims, simplifying problems. The teacher also formulates activities that drive students' analytical power such as asking information, differentiating, organizing, differentiating, as well as connecting, concluding, giving reasons, choosing, expressing experiences. This Edpuzzle application instills understanding, hones students' analytical power, inspires students in making digital products, because creative students come out from creative teachers.

\section{REFERENCES}

Afriazi, Rudi. 2015. Pembelajaran Aktif, Kreatif, Efektif, Tangguh, Inovatif, dan Mandiri. Jakarta: Halaman Moeka Publishing.

Baxter, P., \& Jack, S. (2008). Qualitative Case Study Methodology: Study Design and Implementation for Novice Researchers in The Qualitative Report, 13(4), 544-559.

Darma, Budi. 2005. Harmonium. Jogja: Pustaka Pelajar.

Dave Meier. 2000. Accelerated Learning: Handbook. Cambridge: Cambrigde University Press.

https://en.wikipedia.org/wiki/Analytical_skill

Hussin, Anealka Aziz. 2018. "Education 4.0" dalam IJELS / Vol 6 (no 3): page 9298. Australian International Academic Centre PTY.LTD. 
Kiong, Tee Tze, et all. 2010. The Evaluation of Thinking Skills based on Taxonomy of Anderson and Krathwohl. Faculty of Technical Education, Universiti Tun Hussein Onn Malaysia. RCEE \& RHEd. Kuching, Sarawak

Lang, Charles, et all. 2017. Handbook of Learning Analytics, First Edition. Creative Commons License 4.0

Mueller, Delbert. 1992. An Interactive Guide to Educational Research. Boston: Allyn and Cacon.

Putra, Nusa. 2012. Research and Development. Jakarta: Rajawali Press.

Richard, J.C, and Rodger, T.S. 2001. Approaches and Methods for Language Teching. Cambridge. Cambridge University Press.

Sani, Ridwan Abdullah. 2019. Pembelajaran Berbasis HOTS. Jakarta:TSmart

Sudjana, Nana dan Ahmad Rivai. 2015. Media Pengajaran. Bandung : Sinar Baru Algensindo.

Susanto. 2015. Rencana Pelaksanaan Pembelajaran Menyatu Koheren dan Operasional. Surabaya: CV Istana Grafika.

Susilana, Rudi dan Cepi Riyana. 2008. Media Pembelajaran. Bandung: CV Wacana Prima.

Uno, Hamzah B dan Satria Koni. 2013. Assessment Pembelajaran. Jakarta: PT. Bumi Aksara.

Wahyudin, Asep. 2018. "Pengembangan Media Pembelajaran Persamaan Kuadrat Melalui Android untuk Meningkatkan Keaktifan Belajar Siswa" (Hal. 32-40) dalam Jurnal Didaktika Pendidikan Dasar. Vol 2, No.1 Mei 2018. Jakarta: Direktorat Pembinaan Guru Pendidikan Dasar.

Walker, Timothy D. 2018. Teach Like Finland. Jakarta:PT.Gramedia.

Karlsson, Malin. 2016. What Is a Case Study? Academy of Business, Engineering and Science, Halmstad University, Halmstad, Halland, Sweden. 